\title{
SETTLEMENT OF MARITAL DISPUTES EFFICACY THROUGH MEDIATION IN THE MANADO RELIGIOUS COURT
}

\author{
Rosdalina Bukido \\ Institut Agama Islam Negeri manado, Indonesia \\ email : rosdalina.bukido@iain-manado.ac.id \\ Irwanyah \\ Universitas Hasanuddin, Makassar, Indonesia \\ email : irwansyahrawydharma@yahoo.com \\ Juliet Ningrum Irawan \\ Institut Agama Islam Negeri Manado \\ email : julietirawan801@gmail.com \\ Misbahul Munir Makka \\ Institut Agama Islam Negeri Manado \\ email : misbahulmakk66@gmail.com
}

\begin{abstract}
This study discusses the procedure of divorce settlement through mediation in the Manado Religious Court. This study aims are to know the Procedure of Mediation in the Manado Religious Court and to analyze the Effectiveness of Mediation in the Manado Religious Court. This study was juridical empirical research or sociological legal research. It was qualitative research with the type of descriptive research by using inductive method of thinking and analyze descriptively. This study used the legislative approach, case approach, sociological approach, and conceptual approach. The results show that determination by Mediator in the Manado Religious Court shall not only be determined by the judges, but given the opportunity to the parties to make a selection. Mediation of the marital case in Manado Religious Court has not run effectively. This can be perceptible that the mediation outcomes have decreased every year. In 2015, there were 106 cases which is 6 cases were successfully mediated. In 2016, there were 94 cases that only 3 cases were successfully mediated. Last in 2017, there were 76 cases, which is only 1 case was successfully mediated.
\end{abstract}

\section{Keywords: Effectiveness, Marital Disputes, Mediation}

\section{INTRODUCTION}

Marriage is Allah's command. The order of marriage is intended to regulate human life in interacting with each other. Legal relations within the household occasionally lead to conflicts that eventually the settlement leads them to the judiciary. Religious Court as an institution having the authority to settle marital cases has a very important role in minimizing divorce in society. The settlement stage of cases based on the procedural law before the reading of a lawsuit in the divorce case is mediation of the parties conducted by the Mediator (in this case is the judge of the Manado Religious Court).

The settlement of disputes through mediation may be equivalent to dispute settlement through "hakam" and its operational form is "tahkim", as it is stated 
in the Qur'an. Conflict that continues to be a dispute in the court mostly occurs in the law states of the Republic of Indonesia, both criminal and civil cases.

In term of the subject, the dispute-leading conflict is a type of individual, group, and family one. The conflict occurring in the community continues to be the case if the person feels his/her rights are disrupted and then he/she submits or files a lawsuit in the court and then being officially registered it turns into a case. In connection with this case handling in Indonesia, at the present it has caused a serious problem of case accumulation either in first, appeal, or cassation level.

The philosophical foundation of conflict resolution through mediation was once carried out by Muhammad Rasulullah $S A W$, before and after being an apostle. The process of resolving conflicts (disputes) can be found in the event of the re-laying of "Hajar Aswad (black stone on the side of the Kabah) and the Hudaibiyah treaty, both of which are well known to Muslims worldwide, and therefore generally accepted. The re-laying of Hajar Aswad and Hudaibiyah treaty had value and strategy of conflict resolution (dispute) especially mediation and negotiation, that these two events have the same perspective which is to realize peace.

One of the mediation case settlements is a marital case. The settlement of marital cases usually goes through mediation. Mediation is a way of dispute resolution through the negotiation process to gain agreement of the parties assisted by mediator and has many advantages, such as fast, confidential, inexpensive, fair, and successful process. This settlement shall be a top priority for judges as Mediators to minimize divorce rates.

Head of Women Empowerment and Child Protection Agency (BP3A) North Sulawesi Provincial Government, Erny Tumundo stated that the divorce rate in "Bumi Nyiur Melambai" Region continues to increase every year. For in 2013, Tumundo explained, based on divorce data from the District Court (PN) in North Sulawesi it reached 865 cases in 2013, while data from the Religious Court (PA) was 1041 cases.

In 2012, the Judge of Manado Religious Court has resolved 169 cases filed by the wife (wife-initiated divorce), 69 cases were filed by the husband (husband-initiated divorce). In 2013, the wife-initiated divorce was 189 cases, while the husband-initiated divorce was 86 cases. In 2014, the wife-initiated divorce was 225 cases, while the husbandinitiated divorce was 104 cases. This implies that the divorce rate occurring in the society is dominated by lawsuits filed by the wife due to inharmonious family life, moral crisis, and lack of responsibility. ${ }^{1}$

This research discusses the procedure of divorce settlement through mediation in the Manado Religious Court. This study aims are to know the Procedure of Mediation in the Manado Religious Court and to analyze the effectiveness of mediation in the Manado Religious Court. This study is a juridical empirical research or sociological law research. It was qualitative research with the type of descriptive research by using inductive method of thinking and descriptive analysis. This study used the legislative approach, case approach, sociological approach, and conceptual approach.

The research on the effectiveness of marriage dispute settlement through mediation in the Manado Religious Court was conducted in Manado City, North Sulawesi Province. The populations in this study were all judges, clerks, advocates, and the litigants in the Manado Religious Courts over the last 3 years (2015-2017). The technique of data

${ }^{1}$ Tonny Sumakul, Angka Perceraian di Sulut Tinggi,http://www.manadotoday.co.id/ 2015/02/809/ Accessed on 5th May 2019, 11.00 Central Indonesia Time 
collection was collected through observation, interview and document study. Data processing was done through editing and coding. This study used descriptive analysis method. A descriptive method is a method in investigating the status of human groups, an object, a set of conditions, a system of thinking, or a class of events in the present. The purpose of this descriptive research is to make descriptive, images or portrayal systematically, factually and actually concerning facts, properties, and correlation between the investigated phenomenons.

\section{ANALYSIS AND DISCUSSION}

\section{Mediation Procedure in the Manado Religious Court}

Mediation can also be interpreted as a shorter and cheaper dispute resolution process, providing greater access to the parties with the discovery of a satisfactory dispute resolution and a sense of justice. Instead of settling through a verdict, wherein each party's soul there is no complete solution, the loser still feels frustrated and does not just accept his defeat. ${ }^{2}$

Formally, the term mediation in Indonesia has been used since the enactment of UU Number 30 of 1999 concerning Arbitration and Alternative Dispute Resolution. This law can be said as the beginning of the introduction of mediation in Indonesia, but the clauses governing mediation in this law are very minimal. UU Number 30 of 1999 no more just introducing that mediation is an alternative way of resolving disputes outside the court, in addition to arbitration, conciliation, and so on. But on the contrary, this law is more in-depth and focuses on regulations regarding arbitration. ${ }^{3}$

Mediation in the Manado Religious Courts is one of the most important stages, this can be evident in the majority of respondents who have the same opinion on this statement, as it is also confirmed by PERMA Number 1 Year 2016 in Article 4 paragraph (1) which reads "All civil disputes to be submitted to the Court, including an opposition case (verzet) on the verdict of verstek and opposition of the litigants (partijverzet) or the third party (derdenverzet) on the execution of decision which has a permanent legal force shall first seek settlement through Mediation, unless stipulated otherwise under the Regulation of the Supreme Court."

In relation to the determination of Mediators in the Manado Religious Courts, some respondents agreed that the Mediator is determined by the Panel of Judges in a case while some of them disagreed. PERMA Number 1 Year 2016 in Article 3 paragraph (5), however, clearly stipulated that the appointment of the Mediator is the authority of the Panel of Judges, and the designated Mediator is the Mediator of the Judge who is not the Judge of the Trial Court. The obligation to observe PERMA Number 1 of 2016 is also referred to in article 2, "The provisions concerning Mediation Procedures in this Supreme Court Regulation apply in the process of litigation in the Courts both within the General Courts and Religious Courts." On the other hand, the litigants are also given the opportunity to make a selection of the Mediator as referred to in Article 20 paragraph (1) to paragraph (3) and then the Mediator shall be appointed by the Chairman of the Panel of judges of the Trial Court as referred to in Article 20 paragraph (4) to (6).

\footnotetext{
${ }^{2}$ Mardalena Hanifah, 2016, "KajianYuridis : Mediasi Sebagai Alternatif Penyelesaian Sengketa Perdata Di Pengadilan," ADHAPER: Jurnal Hukum Acara Perdata Vol. 2, No. 1, p. 12

${ }^{3}$ Dedy Mulyana, 2019, Kekuatan Hukum Hasil Mediasi di Luar Pengadilan Menurut Hukum Positif, Jurnal Wawasan Yuridika Vol. 3 No. 2 p. 184
} 
Through PERMA Number 1 Year 2008, mediation has been integrated into the justice system and is called judicial mediation. Every civil case filed in court must first be settled through mediation. Mediation in the court is conducted by judge mediators and non-judge mediators who have participated in the Mediator Professional Profession Education (PKPM) organized by institutions that have been accredited by the Supreme Court. In carrying out their duties and functions, they must comply with the provisions of PERMA Number. 1 of 2008 and the Mediator Code of Conduct created by the Supreme Court.

At technical of execution, most of all judges in Religion Court act as mediator, because Chief Justice has to show and mention the name of mediator at least 5 . This matter meant that all judge by chain can function as mediator for the process of mediation, besides executing especial duty as judge for the process of litigation. Another target of coalescence all this judge is to facilitate at law the parties chose it as a mediator to the solving of its case. ${ }^{4}$

The above mentioned affirms the statement that the Mediator in the Manado Religious Court is well received by the litigants, whether or not that the Mediator is accepted by the litigants, as the Mediator is appointed directly by the Chairman of the Court. It is also approved by most respondents.

Most respondents agree that before the Mediator handling a case starts mediation, he/ she first explains the matters relating to mediation. This is in line with the regulation on PERMA Number 1 Year 2016 in Article 14 on the Stages of the Mediator Task namely: ${ }^{5}$ 1. introduce themselves and allowing the Parties to introduce themselves to each other;

2. explain the purpose, goals, and nature of Mediation to the Parties;

3. clarify the neutral and non-decision-making position and role of the Mediator;

4. establish the rules of mediation with the Parties;

5. explains that the Mediator may hold meetings with one party without the presence of the others (caucus);

6. prepare a Mediation schedule with the Parties;

7. fill out the mediation schedule form.

8. provide opportunities to the Parties to address issues and proposals for peace;

9. make an inventory of problems and scheduling discussion based on priority scale;

10. facilitate and encourage the Parties to:

a. explore and discover the interests of the Parties;

b. seek the best possible solutions for the Parties; and

c. work together to reach completion;

11. assist the Parties in preparing and formulating the Peace Agreement;

12. submit reports on the success, failure and/or non-performance of Mediation to the Judge of the Trial Court;

13. declare one of the Parties who have no good intentions and submit to the Judge of the Trial Court;

14. other tasks in carrying out its function

Based on PERMA Number 1 Year 2016 in Section 14 concerning the Stages of Mediator Tasks above, the Mediator shall provide advice and discourse to the litigants.In Section

${ }^{4}$ Muhammad Saifullah, 2015, Efektivitas Mediasi Dalam Penyelesaian PerkaraPerceraian Di Pengadilan Agama Jawa Tengah, AL-AHKAM, Vol. 25 Number 2, p. 188 166

${ }^{5}$ Syahrisal Abbas, 2011, Mediasi dalam Hukum Syariah, Hukum Adat \& Hukum Nasional, Kencana, Jakarta, p. 
5 PERMA Number 1 of 2008 About Procedure of Mediation in Judicial, mentioned that someone is able to become mediator in the trial of divorce cases, must meet the several requirements are; 1 ) they have owned certificate of mediator the obtained after following training carried out by institute which have obtained accreditation of MA RI and; 2) If in region a Justice no judge, advocate, academician punish and profession is not law which have certificate of mediator, judge in authoritative pertinent Justice environment run function of mediator. ${ }^{6}$

Subsequently, the mediation is conducted in several stages, of which details are referred to in PERMA Number 1 Year 2016 in Chapter V on the Stages of the Mediation Processes article 24 to 32 , and the majority of respondents stated that mediation in marital cases was committed more than once. ${ }^{7}$ Agreements in mediation are left entirely to the parties without intervention of the mediator as referred to in articles 27 to 31 PERMA Number 1 Year 2016.

In the Manado Religious Courts during the settlement of mediation cases stated that the litigants are not always represented by their attorneys. Most cases were personally attended by the litigants without representation of their attorneys or the litigants did not attend the mediation process without representation of their attorneys. If the attorney attends the mediation process, then the attorney shall perform the obligation as referred to in Article 18 PERMA Number 1 Year 2016.

Mediation is carried out subsequent to the parties are summoned legally and appropriately. The summons must be fulfilled by the litigants that the parties can fulfill the provisions of good faith in mediation as referred to in Article 7 of PERMA Number 1 Year 2016 on the Obligation of Attending Mediation. ${ }^{8}$

A peace agreement or agreement resulting from the mediation has the legal force as other ordinary agreements (for instance sale and purchase agreements) which only explain the occurrence of legal relations between the parties that made it. If in the future there is a party who does not have a good intention to violate the agreement, then the other injured party can file a default in court. Thus, the outcome of the peace as mentioned above does not yet have legal certainty. If an agreement comes out of the mediation process, the parties sign the agreement and must register with the District Court within 30 days of the signing. The agreement, based on Article 6 paragraph (7) of Law Number 30 Year 1999 has a final and binding nature. However, the nature of the verdict is final and binding, the implementation is based on the goodwill of the parties. However, if one party turns out to not implement the agreement in the future, then the agreement that they made even if it was registered in court, still does not have the executive power. ${ }^{9}$

Most of the respondents stated that the settlement of marital disputes through mediation could minimize the divorce rate in the Manado Religious Court. It can be evident in the presence of mediators who seek peace treaty as referred to in article 14 of PERMA Number 1 Year 2016.

\footnotetext{
${ }^{6}$ Ridwan Jamal, 2017, Resolusi Konflik Perkawinan Melalui Mediasi Dalam Perkara Perceraian Di Pengadilan Agama Manado, Jurnal Ilmiah Al-Syir'ah, Volume 15 Number 2, p. 151

${ }^{7}$ Achmad Ali, 2012, Sosiologi Hukum Kajian Empiris Terhadap Pengadilan, Kencana, Jakarta, T.th. p. 27

${ }^{8}$ Sofiani, Triana. 2010, Efektifitas Mediasi Perkara Perceraian Pasca PERMA Nomor 1 Tahun 2008 Di Pengadilan Agama, JurnalPenelitian, Volume. 7, Number 2, p. 6

${ }^{9}$ Sri Hajati, Agus Sekarmadji, dan Sri Winarsi, 2014, "Model Penyelesaian Sengketa Pertanahan Melalui Mediasi Berkepastian Hukum," Jurnal Dinamika Hukum Volume 14 Number 1 36-48, p. 42
} 
In line with the above statement, the purpose of mediation is to create an agreement of the parties in the case of marital dispute resolution, in order to avoid the risk of divorce.

Therefore it requires a process of socialization to the public by the mediator on the process of mediation, as well as the mediation procedures established by the Supreme Court.

\section{Efficacy of Mediation in the Manado Religious Court}

Mediation or alternative dispute resolution (ADR) is a form of dispute resolution outside the court based on an agreement (consensus) conducted by the parties to the dispute. The development and empowerment of mediation as an alternative dispute resolution in Indonesia is the right choice to reduce the swift flow of cases that go to court; besides cultural considerations. Where the pattern of dispute resolution with a consensus approach and consensus agreement has long been known and rooted in Indonesian society. also empirically, dispute resolution through mediation has several advantages when compared to litigation settlement. ${ }^{10}$

The Supreme Court persistence to integrate the mediation institution into the proceedings in the courts is intended to be one of the most effective instruments to deal with the problem of court cases accumulation, including divorce cases in the Religious Court and strengthen and maximize the functioning of non-justice institutions in dispute resolution in addition to litigation (adjudication). ${ }^{11}$

The positive impact of mediation is also felt by the community, that the mediator has made every effort to calm. Until there is a written agreement. But, for abstract foreigners must see changes in husband or wife to the schedule of meetings before the next trial.

Meanwhile, some are "divorced" but their matters are agreed in the mediation process, such as childcare, which must be met. The various responses and statements of the parties above indicate that after going through the mediation stage most of the parties continued to pursue the case, meaning that the mediation results were reported to have failed because they did not produce an agreement to revoke a clause. However, the parties stated that many of the things they obtained were, among others: a) Obtaining clarity on the problems faced, so that they could experience a passive divorce process; b) communication with the enemy is established; c) express all thoughts and feelings during the hidden time; d) acceptance of the party suing in patience; e) readiness to attend the meeting before the next session; f) good agreement in establishing divorce that is relevant in childcare matters; g) advice on entering into a divorce life. ${ }^{12}$

The court, both in terms of time, cost and energy used is based on the article above, so in civil cases, mediation efforts are a direct obligation that must be done in the trial process. This is intended that mediation can be used as a concept to make it easier for parties who are litigants to obtain mutual agreement and provide fairness derived from the active behavior of the parties themselves and the things desired in the mediation process. The use of court mediation institutions is more profitable because it is quick to resolve Civil Disputes. The mediation mechanism in the dispute resolution process

\footnotetext{
${ }^{10}$ Muhamad Noupel, 2018, Prospek Dan Pemberdayaan Mediasi Sebagai Cara Penyelesaian Alternatif Perselisihan Hukum Akibat Pemberitaan Pers, Syntax Literate: Jurnal Ilmiah Indonesia, Volume 3 Number 1, p. 97

${ }^{11}$ Wirhanuddin, 2016, Deskripsi Tentang Mediasi Di Pengadilan Tinggi Agama Makassar: Perspektif Hukum Islam, $A L-F I K R$, Volume 20 Number 2, 279-303, p. 282

${ }^{12}$ Erik Sabti Rahmawati, 2016, Implikasi MediasiBagi Para Pihak yang Berperkara di Pengadilan Agama Malang, De Jure: Jurnal Hukum dan Syari'ah, Volume 8 Number 1, p. 12
} 
in the Court also encourages peaceful efforts as the main solution by the parties to the dispute. ${ }^{13}$

Soekanto explained that the legal culture that supports the effectiveness of law enforcement depends on community factors and cultural factors. Community factors are people's perceptions of law, so law is seen as the norm, knowledge and legal order. Whereas the cultural factor is a system that includes values that underlie applicable law, values that are considered good (so followed), and values that are considered bad (so avoided). Mediation as a legal product that must be applied in the dispute resolution system in the court must be carried out. Section 2 paragraph 3 of PERMA Number 1 of 2008 emphasizes that: "Not following mediation procedures based on this regulation is a violation of the provisions of Section $130 \mathrm{HIR}$ and or Section $154 \mathrm{Rbg}$ which results in a decision being null and void". For the "coercion" of this article, law enforcement and the community must implement it. The community as one of the supporters of the running of the mediation legal system in court is reluctant to mediate. Based on the results of interviews and observations of researchers, the reluctance of the community who are plaintiffs to divorce is due to a lack of understanding of mediation and the low culture of the community to make peace. ${ }^{14}$

According to Soekanto, there are four indicators to measure the effectiveness of a regulation, among others: firstly, referred to the law itself; secondly, the enforcing officers; thirdly, facilities supporting the enforcement of the law; and fourth, the people affected by the regulation.

The first factor, referred to the law or the rule itself. According to Fuller, every rule (laws, government regulations, and others) must fulfill eight principles of legality, including:

1. There must be norms and rules previously adhered in the society;

2. The legislation must be properly socialized, not only in legal fiction that all persons are deemed to recognize the law shortly after it is promulgated;

3. Formulation of rules is made clear to avoid legal interpretation;

4. The rules shall not be retroactive, according to the universally applicable principle of legality;

5. The Law governs concrete and realistic matters that it is easy to implement,

6. The Law shall not conflict with each other,

7. The law shall be consistent, non-changeable or ad hoc; and

8. There is an equivalent between regulation and daily execution.

Judging from the consensual nature or consensus and collaborative, mediation always results in dispute resolution by winning the parties (winwin solution), so as not to harm the parties who litigate. Mediation is one of the alternative solutions to dispute which is relatively inexpensive and does not take a long time compared to litigation through litigation. Besides that, the results obtained during the mediation process are collective agreements by the parties, so that the parties to the dispute do not raise objections to what has been agreed. ${ }^{15}$

${ }^{13}$ Oki Basuki Rachmat dan Mahmul Siregar, 2013, Pelaksanaan Mediasi Dalam Perkara Perdata Berdasarkan Peraturan Mahkamah Agung Nomor 01 Tahun 2008 di Pengadilan Negeri Stabat, Jurnal Mercatoria, Volume 6 Number 2, p. 204

${ }_{14}$ Muhammad Saifullah, 2015, EfektivitasMediasiDalamPenyelesaianPerkaraPerceraian Di Pengadilan Agama Jawa Tengah, AL-AHKAM, Volume 25 Number 2 p. 181-204

15 Sri Puspitaningrum, 2018, Mediasi Sebagai Upaya Penyelesaian Sengketa Perdata Di Pengadilan, Jurnal Spektrum Hukum, Volume 15 Number 2, 275-299, p. 294 
In the description of the results of the study, some respondents stated that the procedures and mediation measures on the marital case in the Manado Religious Court need to be optimized and streamlined over again. But some disagreed that because they considered that the mediation measures in the Manado Religious Court were in accordance with the prevailing rules and has been implemented optimally and effectively.

Mediationin Religion court of Manado is to represent one of the very important steps, this matter can be proved by halves is big responder agree this statement, is also proved with existence of PERMA Number 1 of 2016 section 4 sentence (1) sounding "All brought to trial civil dispute the including case of resistance (verzet) of decision of verstek and resistance of at law party (verzetpartij) and also third party (verzetderden) to execution of decision which haswith power of law remain to, is obliged to beforehand strived by solution" 16

Solving Of Dispute through Mediation, Role of Advocate in Giving Legal Aid [pass/ through] mediation except determined other accordingto this PERMA." In reality, in several cases, especially in the aftermath of PERMA Number 1 of 2008 divorce, it has not been effective in its implementation. This is due to some starting from the mediator himself, the parties, the period of mediation, facilities and infrastructure that have not been representative and the cumulation of divorce cases with the case of acessoir. ${ }^{17}$ This is evident in view of the last 3 years' data that there were far fewer successful mediations than failed, that is, in 2015, mediation received were 347 cases, 106 mediated cases, which succeeded in mediating only 6 temporary cases, while those that failed were mediation. 100 cases and 241 other cases did not qualify for mediation. In 2016, mediation received was 510 cases, mediated by 94 cases, mediated by only 3 cases while those that failed were 91 cases and 416 other cases were not eligible for mediation. In 2017, mediation received was 359 cases, 76 cases were mediated, which succeeded in mediating only 1 case, while 75 cases failed and 283 other cases did not meet the requirements for mediation.

It is true that the process of settling marital disputes through mediation is based on the principle of negotiation under the mandate of PERMA No. 1 of 2016. In fact, the mediation procedure is in accordance with the rules, but the above data explicitly states that successful mediation is decreasing every year, indicating that mediation in the Manado Religious Court has not run effectively as expected.

\section{CONCLUSION}

The procedure for divorce settlement through mediation in the Manado Religious Court is carried out in accordance with Article 14 PERMA Number 1 of 2016. In relation to the determination of Mediator in the Manado Religious Court, some respondents agreed that the Mediator is determined by the Panel of Judges in a case while some disagreed with it. However, PERMA Number 1 of 2016 in Article 3 paragraph (5) clearly stipulated that the appointment of the Mediator is the authority of the Panel of Judges, and the designated Mediator is the Mediator of the Judge who is not the Judge of the Trial Court. The obligation to observe PERMA Number 1 of 2016 is also clarified in article 2, "The provisions concerning Mediation Procedures in this Supreme Court Regulation apply in the process of litigation in the Courts both within the General Courts and Religious Courts." On the other hand, the parties are also given the opportunity to make

\footnotetext{
${ }^{16}$ Rosdalina Bukido, 2018, Penyelesaian Sengketa Melalui Mediasi Peran Advokad Dalam Memberikan Bantuan Hukum, Istana Agensi, Yogyakarta, p. 27-28

${ }^{17}$ Sofiani, Triana. EfektifitasMediasiPerkaraPerceraianPasca PERMA nomor 1 Tahun 2008 Di Pengadilan Agama
} 
a selection of the Mediator as referred to in Article 20 paragraph (1) to paragraph (3) and then the Mediator shall be appointed by the Chairman of the Panel of judges of the Trial Court as referred to in Article 20 paragraph (4) to (6).The factors underlying the settlement of divorce cases through mediation have not been effective is effectiveness of the implementation of the regulations or legal system governing the mediation. Mediation procedures and measures in the marital case in the Manado Religious Court need to be optimized and streamlined over again. But some disagreed as they considered that the mediation measures in the Manado Religious Court are in accordance with the existing rules and have been implemented optimally and effectively. It is obvious, however, from the last 3 years data that successful mediations are far less than failed mediation. That is, in 2015, the received mediation was 347 cases, of which 106 cases were mediated, which succeeded in mediating only 6 cases while the failed ones were 100 cases and 241 other cases were not eligible for mediation. In 2016, the received mediation was 510 cases, 94 cases were mediated, which succeeded in mediating only 3 while the failed ones were 91 cases and 416 other cases were not eligible for mediation. In 2017, the received mediation was 359 cases, 76 cases were mediated, which succeeded in mediating only 1 case while the failed ones were 75 cases and 283 other cases were not eligible for mediation.

\section{REFERENCES}

\section{Books}

Abbas, Syahrisal, (2011), Mediasi dalam Hukum Syariah, Hukum Adat. \& Hukum Nasional, Kencana, Jakarta.

Ali, Achmad, (2012), Sosiologi Hukum Kajian Empiris Terhadap Pengadilan, Jakarta: Kencana.

Bukido, Rosdalina (2018), Penyelesaian Sengketa Melalui Mediasi Peran Advokad Dalam Memberikan Bantuan Hukum, Istana Agensi, Yogyakarta

\section{Journal}

Bukido,Rosdalina. (2018). Perkawinan Di Bawah Umur: Penyebab Dan Solusinya, Jurisprudentie: Jurusanllmu Hukum Fakultas Syariah dan Hukum, Vol. 5 No.2.

Hajati, Sri.,Sekarmadji, Agus., dan Winarsi, Sri. (2014). "Model Penyelesaian Sengketa Pertanahan Melalui Mediasi Berkepastian Hukum," Jurnal Dinamika Hukum 14, No. 1, 36-48

Hanifah,Mardalena. (2016). "Kajian Yuridis :Mediasi Sebagai Alternatif Penyelesaian Sengketa Perdata Di Pengadilan," ADHAPER:Jurnal Hukum Acara Perdata Vol. 2, No. 1

Jamal, Ridwan. (2017). Resolusi Konflik Perkawinan Melalui Mediasi Dalam Perkara Perceraian Di Pengadilan Agama Manado, Jurnal Ilmiah Al-Syir'ah, Vol. 15 No.2.

Mulyana, Dedy. (2019). Kekuatan Hukum Hasil Mediasi di Luar Pengadilan Menurut Hukum Positif, Jurnal Wawasan Yuridika Vol. 3 No. 2, 177-198

Noupel, Muhamad. (2018). Prospek Dan Pemberdayaan Mediasi Sebagai Cara

\section{IUS Kajian Hukum dan Keadilan}


Penyelesaian Alternatif Perselisihan Hukum Akibat Pemberitaan Pers, Syntax Literate: Jurnal Mmiah Indonesia, Vol. 3, No. 1, 87-98

Puspitaningrum, Sri. (2018). Mediasi Sebagai Upaya Penyelesaian Sengketa Perdata Di Pengadilan, Jurnal Spektrum Hukum, Vol. 15 No. 2, 275-299

Rachmat,Oki BasukidanSiregar, Mahmul, 2013. Pelaksanaan Mediasi Dalam Perkara Perdata Berdasarkan Peraturan Mahkamah Agung Nomor 01 Tahun 2008 Di Pengadilan Negeri Stabat, Jurnal Mercatoria, Vol. 6 No. 2

Rahmawati, Erik Sabti. 2016. Implikasi Mediasi Bagi Para Pihak yang Berperkara di Pengadilan Agama Malang, De Jure : Jurnal Hukumdan Syari'ah, Vol. 8 No. 1.

Saifullah, Muhammad. 2015, Efektivitas Mediasi Dalam Penyelesaian Perkara Perceraian Di Pengadilan Agama Jawa Tengah, AL-AHKAM, Vol. 25 No. 2.

Sofiani, Triana, 2010. Efektifitas Mediasi Perkara Perceraian Pasca PERMA nomor 1 Tahun 2008 Di Pengadilan Agama,Jurnal Penelitian, Vol. 7, No. 2.

Wirhanuddin, 2016. Deskripsi Tentang Mediasi Di Pengadilan Tinggi Agama Makassar: Perspektif Hukum Islam, AL-FIKR, Vol. 20 No. 2.

\section{PeraturanPerudang-undangan.}

PERMA Nomor 1 Tahun 2016 Tentang Prosedur Mediasi di Pengadilan

\section{Website}

Tonny Sumakul, Angka Perceraian di Sulut Tinggi, http://www.manadotoday.co.id/ 2015/02/809/ . Diakseskamis 5 Mei 2019 pukul 11.00 Wita. 